\title{
Sistem Pendukung Keputusan Penentuan Lokasi Toko Terbaik Pada PT. Sumber Alfaria Trijaya Menggunakan Metode Analytical Hierarchy Process
}

Article Info

Article history:

Received 20 February, 2021

Revised 23 march, 2021

Accepted 01 April, 2021

\section{Keywords:}

Decision Support System, Location Determination, Analytical Hierarchy Process

\begin{abstract}
Decision Support System is an interactive computer-based system that helps decision making by utilizing data and models to solve unstructured problems. Basically, DSS is designed to support all stages of decision making, from identifying problems, selecting relevant data, determining the approach used in the decision-making process, to evaluating the selection. AHP is a decision support model developed by Thomas L. Saaty. This decision support model will describe complex multi-factor or multi-criteria problems into a hierarchy, the hierarchy is defined as a representation of a complex problem in a multi-level structure where the first level is the goal, followed by the level of factors, criteria, sub criteria, and so on down to the last level of alternatives. With a hierarchy, a complex problem can be broken down into groups which are then arranged into a hierarchical form so that the problem will appear more structured and systematic. In order to compete with several similar companies, PT. Sumber Alfaria Trijaya must be able to provide optimal service not only for consumers, but also for staff and employees in order to work optimally. To be able to answer these challenges, the technology used must be able to balance the need for it. Because this company is engaged in retail, problems will arise either in the store, in the warehouse or in the system used. With a hierarchy, a complex problem can be broken down into groups which are then arranged into a hierarchical form so that the problem will appear more structured and systematic.
\end{abstract}

This is an open access article under the CC BY-SA license.

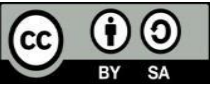

Corresponding Author:

Nurlaeli Waruwu

Universitas Imelda, Manajemen Informatika, Medan, Indonesia

Email Address: nurlaeliwaruwu@gmail.com

(C) 2021 The Author: Published by. Cattleya Darmaya Fortuna

\section{Pendahuluan}

Dewasa ini dunia usaha mengharuskan pengusaha baru jeli dalam menentukan lokasi dan memahami kebutuhan konsumen karena akhir-akhir ini perusahaan sulit membedakan mana yang menjadi kebutuhan dan mana yang menjadi keinginan dari konsumen [1]. Masingmasing usaha berusaha mengembangkan usahanya dengan membuka cabang pada beberapa wilayah dan lokasi [2]. Penilaian setiap pengambil keputusan masih dilakukansecara manual sehingga penilaiannya masih subjektif [3] untuk memperoleh informasi yang 


\section{Nurlaeli Waruwu}

doi.org/10.54209/jatilima. v2i3.143

akurat [4] demi mendapatkan suatu lokasi yang ideal untuk mendirikan suatu cabang, maka dibutuhkan sistem pendukung keputusan untuk membantu menentukan lokasi yang terbaik [5]. Adapun penentuan lokasi [6][7] tersebut memiliki faktor-faktor yang perlu dipertimbangkan antara lain dilihat dari lingkungan masyarakat, kedekatan dengan pasar, adanya tenaga kerja yang murah, kedekatan dengan bahan mentah, tersedianya fasilitas dan biaya transportasi serta tersedianya lahan untuk perluasan usahanya [8]. Sistem pendukung keputusan merupakan suatu sistem yang mampu memecahkan masalah secara efesian, efektif, yang bertujuan untuk membantu pengambilan keputusan dengan memilih berbagai alternatif keputusan [9]. Sistem pendukung keputusan memberikan suatu keputusan yang bersifat semiterstruktur, dimana tidak seorangpun tahu secara pasti bagaimana keputusan seharusnya dibuat [10]. SPK bertujuan untuk menyediakan informasi, membimbing, memberikan prediksi serta mengarahkan kepada pengguna informasi agar dapat melakukan pengambilan keputusan dengan lebih baik [11]. SPK yang dibangun pada riset ini diharapkan mampu menghasilkan rekomendasi dengan memberikan perankingan lokasi kepada pengguna sesuai preferensinya [12]. Metode AHP yaitu suatu metode yang input utamanya adalah persepsi manusia [13]. AHP digunakan untuk memberikan pembobotan pada masing-masing kriteria [14] dan untuk menentukan tingkat kepentingan dari variabel - variabel [15].

\section{Metode}

Metode pengumpulan data yang digunakan dalam menyusun penelitian ini adalah sebagai berikut:

1. Penelitian Lapangan (Pengumpulan data)

Apakah salah satunya?metodekoleksidatadalam penelitian kualitatif yang tidak membutuhkan pengetahuan kemauan yang dalam literatur digunakan dan kemampuan khusus peneliti.

a. Wawancara,

Pengumpulan data dilakukan dengan cara wawancara langsung dengan Toko Terbaik

Pada PT. Sumber Alfaria Trijaya

b. Pengamatan

Merupakan metode pengumpulan data dengan cara mengamati dan mempelajari tentang metode pelayanan yang diterapkan PT. Sumber Alfaria Trijaya.

c. studi sastra

Peneliti melakukan studi literatur tentang penerapan metode deskriptif dalam menganalisis penentuan letak toko terbaik.

d. Analisa masalah Yaitu untuk mengetahu dimana posisi yang terbaik untuk membuat took alfaria trijaya.

2. Desain

Penelitian akan dilakukan dengan mengumpulkan data pengaduan masyarakat yang mengajukan izin usaha di kantor kelurahan Dolat Rakyat, data tersebut berjumlah sepuluh pertanyaan yang dibuat oleh peneliti dan disebarluaskan kepada masyarakat kemudian data tersebut diolah dengan menggunakan metode deskriptif.

\section{Hasil dan Pembahasan}

Algoritma sistem pendukung keputusan penentuan lokasi toko pada PT. Sumber Alfaria Trijaya Tbk adalah sebagai berikut: 


\section{Nurlaeli Waruwu}

doi.org/10.54209/jatilima. v2i3.143

\section{Implementasi Sistem}

Implementasi sistem merupakan tahap lanjutan atas apa yang sebelumnya telah dirancang dan melalui suatu proses analisa. Pada tahap ini sebuah sistem benar-benar dibangun secara optimal dengan disesuaikan dengan apa yang ingin dicapai pada perancangan. Namun desain tersebut haruslah disusun dan dibangun dengan berdasarkan analisa terhadap kebutuhan pengguna, serta kelemahan dari sistem yang lama baik itu secara manual atau yang telah terkomputerisasi. Penilaian yang dilakukan adalah untuk memberikan tambahan dan usulan yang kiranya membantu dalam penyelasaian sistem ini. Adapaun perincian evaluasi terhadap sistem pendukung keputusan tersebut dengan menggunakan metode Analytical Hierarchi Process (AHP) dapat dijabarkan sebagai berikut:

1. Sistem pendukung keputusan merupakan sistem yang memberikan penilai berdasarkan perhitungan matematis dengan hasil yang akurat atas dasar perhitungan matriks, belum mampu mengatasi masalah penilaian berdasarkan logika keadaan realita yang terjadi di lapangan.

2. Alternatif yang diberikan masih dapat diubah, hanya saja tetap harus berdasarkan hasil perhitungan nilai kriteria dan bobot. Alternatif tersebut adalah pilihan bagi lokasi yang apabila kriteria yang dimilikinya belum ideal untuk dipilih sebagai lokasi toko.

3. Kriteria dan nilai bobot yang diberikan bukan kepada lokasi toko bukan berdasarkan perhitungan sistem atau lewat media program aplikasi pendukung yang dirancang. Melainkan pemberian kriteria masih tetap dilakukan langsung oleh pihak peraksesan dalam menilai lokasi sebagai calon lokasi toko dengan cara penilaian lapangan (survei) terlebih dahulu. Jadi program aplikasi akan menghitung kriteria nilai bobot sesuai yang disepakati pihak kelurahan atas hasil survei lapangan.

4. Sistem ini masih bersifat offline oleh sebab itu hasil dari perhitungan nilai kriteria bobot serta pemberian alternatif tidak dapat secara langsung dilihat oleh pemilik lahan sebagai calon lokasi toko.

5. Operator dari sistem ini yang dalam hal ini adalah tim Location dari Departemen Property and Development harus mampu minimal untuk memasukan data-data dari hasil penilaian lapangan(survei). Hasil laporan akan dapat langsung dicetak apabila proses pemasukan data telah selesai dilakukan. Laporan yang dihasilkan juga sudah dapat diakses dalam periode tertentu yakni bulanan dan tahunan.

6. Aplikasi bahasa pemrograman yang dipergunakan dalam sistem ini adala Microsoft Visual Basic net 2008 dengan database MySQL dan pengelolaan laporan dengan menggunakan Crystal Report 8.5.

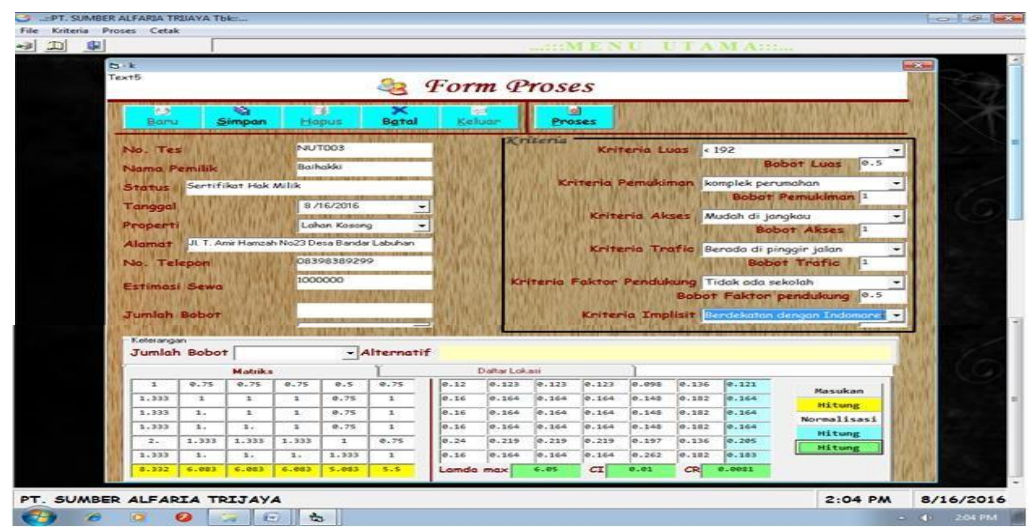

Gambar 1. Tampilan Input Proses dan Perhitungan Matriks 


\section{Nurlaeli Waruwu}

doi.org/10.54209/jatilima. v2i3.143

Tampilan input proses merupakan bentuk proses penetuan lokasi toko yang dihitung berdasarkan penghitungan matriks kriteria bobot.

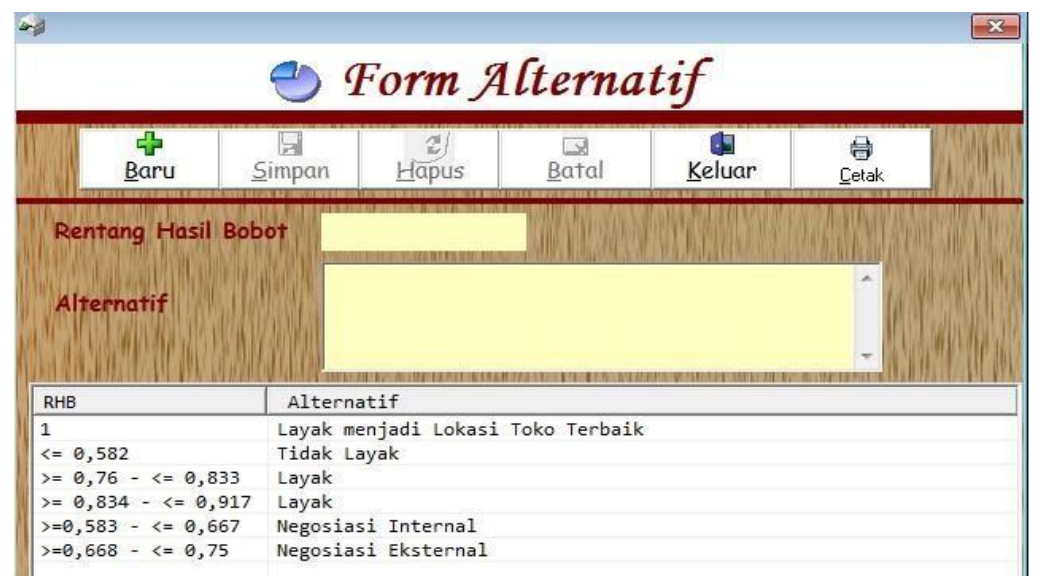

Gambar 2. Tampilan input Alternatif

Tampilan input alternatif adalah tampilan form yang digunakan untuk memberikan alternatif pilihan terhadap jumlah kriteria bobot. Sehingga setiap lokasi toko dapat menerima pinjaman dana sesuai bobot yang dimiliki.

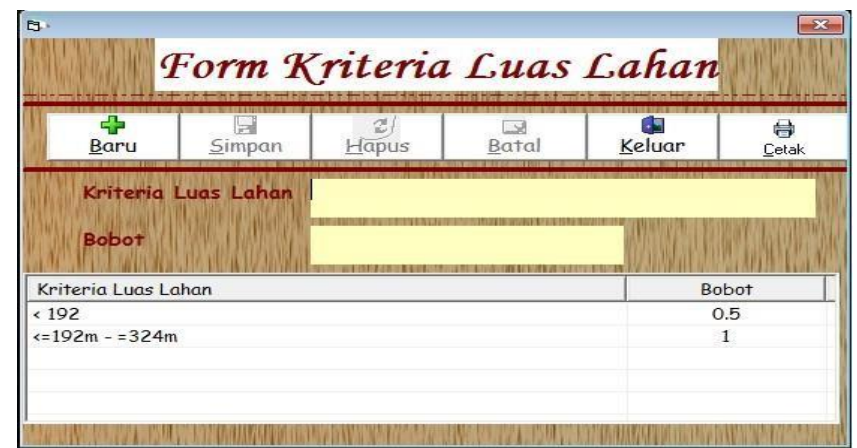

Gambar 3. Tampilan input Kriteria Luas lahan

Tampilan input kriteria luas lahan adalah form yang dirancang untuk memberikan nilai bobot terhadap luas lahan yang dimiliki atau diperoleh calon lokasi toko setiap bulannya.

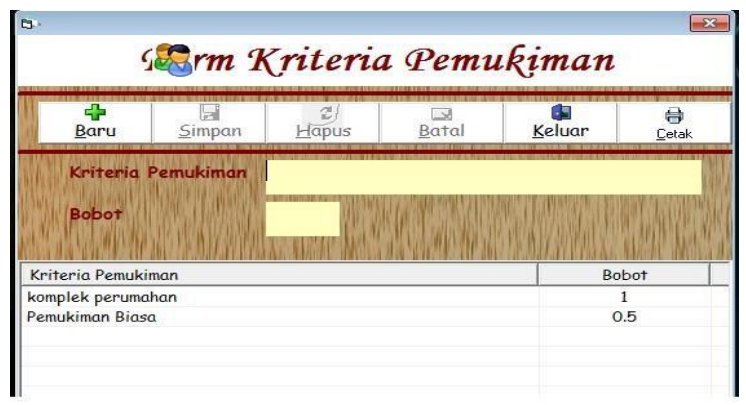

Gambar 4. Tampilan Input Kriteria Padat pemukiman

Tampilan input kriteria padat pemukiman adalah tampilan form yang berfungsi sebagai 


\section{Nurlaeli Waruwu}

doi.org/10.54209/jatilima. v2i3.143

pemberian nilai bobot terhadap kriteria padat pemukiman yang dimiliki calaon lokasi toko.

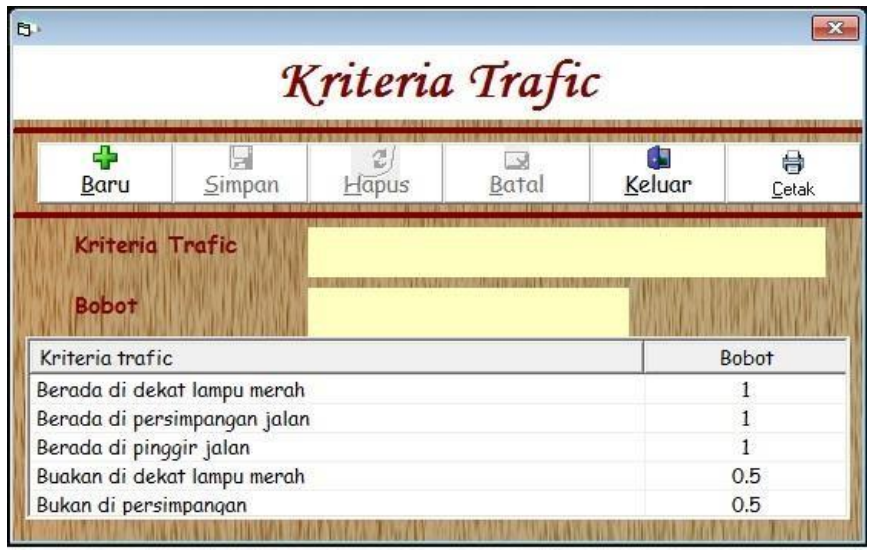

Gambar 5. Kriteria Trafic

Tampilan input kriteria Trafic berfungsi sebagai input dalam pemberian nilai bobot terhadap Trafic keluarga yang dimiliki calon lokasi toko. Berikut adalah gambaran dari tampilan input kriteria Trafic.

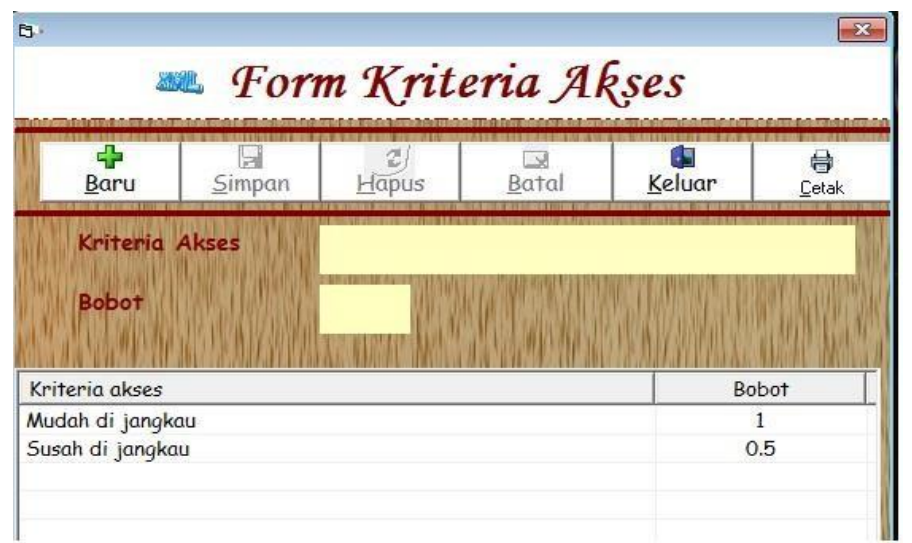

Gambar 6. Tampilan Input Kriteria Akses

Tampilan input kriteria merupakan tampilan masukan yang berfungsi untuk memberikan nilai bobot yang nantinya akan direlasikan pada perhitungan matriks dari transaksi proses lokasi toko.

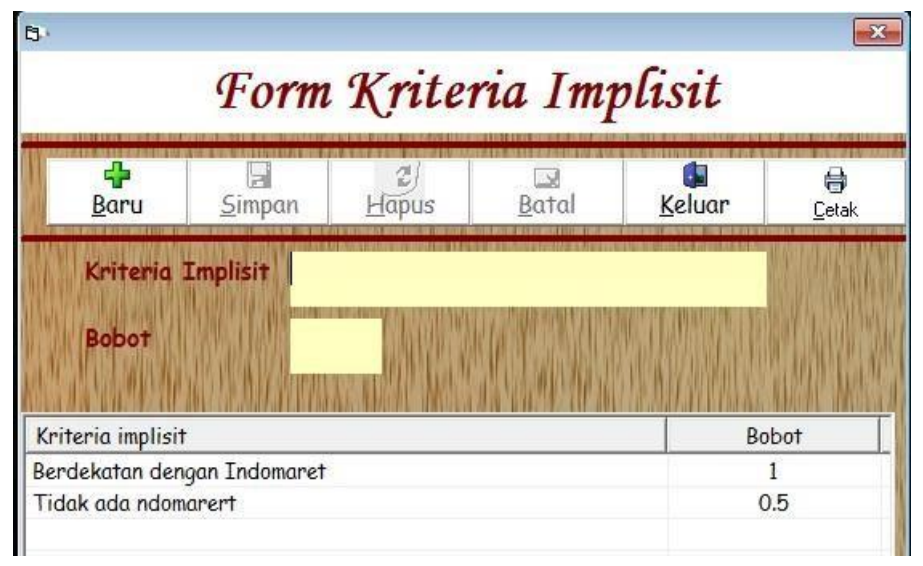

Gambar 7. Kriteria Implisit 


\section{Nurlaeli Waruwu}

doi.org/10.54209/jatilima. v2i3.143

Tampilan input kriteria implisit adalah pemberian bobot terhadap implisit dari calon lokasi toko.

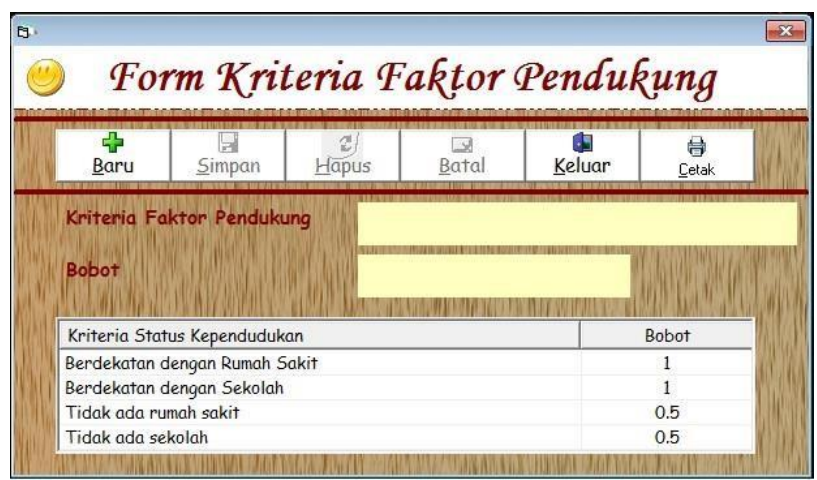

Gambaran 8. Tampilan Input Kriteria Faktor pendukung

Tampilan input kriteria Faktor pendukung adalah tampilan yang dipergunakan untuk memberikan nilai bobot dari Faktor pendukung yang berbeda-beda.

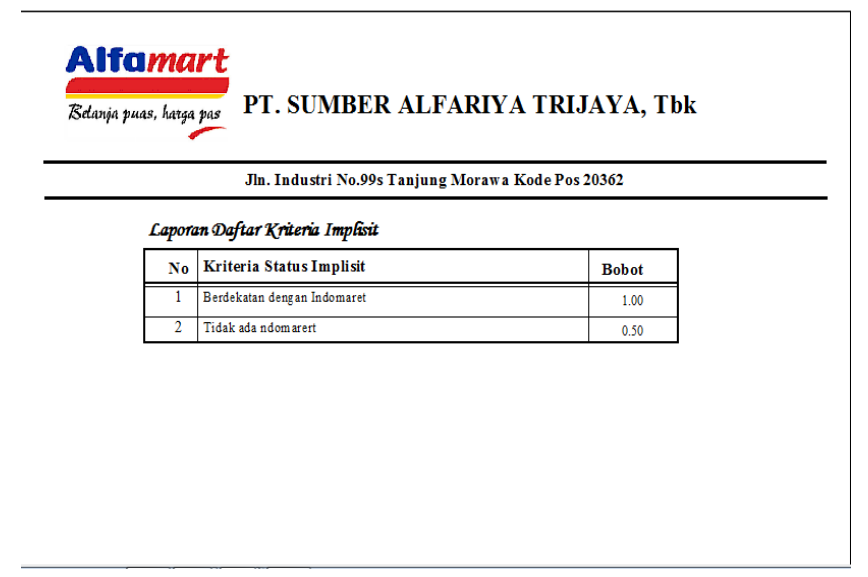

Gambar 9. Laporan Kriteria Faktor Pendukung

Laporan Kriteria implisit berisi kriteria berupa ada tidaknya perusahaan kompetitor yang berada di sekitar lokasi tersebut.

\section{Kesimpulan}

Berdasarkan hasil penelitian dan perencanaan yang telah diuraikan pada bab-bab sebelumnya, maka dapat disimpulkan sebagai berikut: Dalam pemberian keputusan penetuan lokasi toko terbaik pada PT. Sumber Alfaria Trijaya ditentukan dari kriteria-kriteria yang mendukung untuk memberikan keputusan penetuan lokasi toko terbaik dana, seperti, luas lahan, pemukiman penduduk, akses, trafic, faktor pendukung, dan implisit. Sistem yang telah dirancang menggunakan bahasa pemrograman Microsoft Visual Basic 6.0 dengan database Mysql terdiri dari tiap form, tabel, dan laporan. Sistem yan dirancang ini dapat memberikan hasil berupa layak atau tidak layaknya suatu lokasi untuk menjadi lokasi toko terbaik, dengan metode perhitungan Analytical Hierarchy Process.

\section{Reference}

[1] M. Musrifah, M. Arief, and N. Andriani, "Penentuan Lokasi Usaha Berdasarkan 


\section{Nurlaeli Waruwu}

doi.org/10.54209/jatilima. v2i3.143

Pendekatan Mystique (Study Fenomenologi)," J. Stud. Manaj. dan Bisnis, vol. 4, no. 1, 2017.

[2] I. W. K. Suwastika and N. L. A. K. Y. Sarja, "Penentuan Lokasi Pemasaran Produk dengan Menerapkan Metode AHP dan Weighted Product," J. Sist. dan Inform., vol. 10, 2017.

[3] A. Tri Wahyudi, Y. Pradana, and O. Saputro, "Sistem Pendukung Keputusan Kelompok Dalam Penentuan Lokasi Obyek Wisata Terbaik Di Lombok," Tekinfo J. Ilm. Tek. Ind. dan Inf., vol. 6, no. 1, 2017.

[4] B. Andika, M. Dahria, and E. Siregar, "Sistem Pendukung Keputusan Untuk Menentukan Lokasi Pembangunan Perumahan Type 36 M/S Menggunakan Metode Weighted Product Pada Pt.Romeby Kasih Abadi," J. SAINTIKOM (Jurnal Sains Manaj. Inform. dan Komputer), vol. 18, no. 2, 2019.

[5] T. Kristina, "Sistem Pendukung Keputusan Dengan Menggunakan Metode TOPSIS Untuk Pemilihan Lokasi Pendirian Grosir Pulsa," Paradigma, vol. 20, no. 1, 2018.

[6] M. Anshori, A. F. Fudhla, and A. Hidayat, "PENENTUAN LOKASI FASILITAS CROSSDOCK PADA KOTA METROPOLIS DENGAN PENDEKATAN CENTER OF GRAVITY," Tek. Eng. Sains J., vol. 1, no. 2, 2017.

[7] S. Maharani, A. Harsa K, and A. T. Nalarwati, "Sistem Informasi Geografi (SIG) Pencarian ATM Bank Kaltim Terdekat Dengan Geolocation Dan Haversine Formula Berbasis Web," J. INFOTEL, vol. 9, no. 1, 2017.

[8] A. S. Yani, "PENENTUAN LOKASI USAHA YANG STRATEGIS DAN FAST RESPONS PADA UMKM DESA SIPAYUNG KECAMATAN SUKAJAYA KABUPATEN BOGOR," J. Berdaya Mandiri, vol. 2, no. 1, 2020.

[9] Sriani and R. A. Putri, "Analisa Sistem Pendukung Keputusan Menggunakan Metode Topsis Untuk Sistem Penerimaan Pegawai Pada Sma Al Washliyah Tanjung Morawa," J. Ilmu Komput. dan Inform., vol. 02, no. April, 2018.

[10] F. I.-R. P. Computer, "Sistem Pendukung Keputusan Penerimaan Jurnalis Menerapkan MultiObjective Optimization On The Basis Of Ratio Analysis (MOORA)," JURIKOM (Jurnal Ris. Komputer), vol. 5, no. 1, 2018.

[11] S. W. Sari and B. Purba, "Sistem Pendukung Keputusan Pemilihan Ketua Danru Terbaik Menggunakan Metode ARAS," Semin. Nas. Teknol. Komput. Sains SAINTEKS 2019, 2019.

[12] P. A. W. Santiary, P. I. Ciptayani, N. G. A. P. H. Saptarini, and I. K. Swardika, "Sistem Pendukung Keputusan Penentuan Lokasi Wisata dengan Metode Topsis," J. Teknol. Inf. dan Ilmu Komput., vol. 5, no. 5, 2018.

[13] G. P. Sanyoto, R. I. Handayani, and E. Widanengsih, "Sistem Pendukung Keputusan Pemilihan Laptop Untuk Kebutuhan Operasional Dengan Metode AHP (Studi Kasus: Direktorat Pembinaan Kursus Dan Pelatihan Kemdikbud)," J. Pilar Nusa Mandiri, vol. 13, no. 2, 2017.

[14] G. S. Mahendra and K. Y. Ernanda Aryanto, "SPK Penentuan Lokasi ATM Menggunakan Metode AHP dan SAW," J. Nas. Teknol. dan Sist. Inf., vol. 5, no. 1, 2019.

[15] I. B. Rianto and E. B. Santoso, "Penentuan Lokasi Kawasan Industri Tekstil Terpadu di Kabupaten Majalengka," J. Tek. ITS, vol. 7, no. 1, 2018. 